Proceedings of the 33rd Annual Scientific Meeting of the European Embryo Transfer Association (AETE); Bath, United Kingdom, September 8th and 9th, 2017.

\title{
Postpartum uterine infection and endometritis in dairy cattle
}

\author{
Iain Martin Sheldon ${ }^{1}$, Sian E Owens \\ Swansea University Medical School, Swansea, SA2 8PP, United Kingdom.
}

\begin{abstract}
After parturition, uterine involution, regeneration of the endometrium, return of ovarian cyclic activity, and the control of pathogenic bacteria in the uterus is required before cows are likely to conceive again. However, pathogenic bacteria often cause uterine disease in modern dairy cattle, leading to decreased productivity and reduced fertility. This review aims to provide an overview of postpartum uterine infection and disease in dairy cattle. Metritis and endometritis are the main postpartum clinical conditions; although, subclinical endometritis is an emerging issue. Postpartum uterine disease is associated with the isolation of Escherichia coli, Trueperella pyogenes, and anaerobic pathogenic bacteria. Sensing of bacteria or their pathogen-associated molecules, such as lipopolysaccharide, by the innate immune system generates inflammatory responses. Endometrial inflammation includes increased expression of complement, calgranulins, interleukins and acute phase proteins, as well as the chemotaxis of neutrophils and macrophages to the site of infection. Uterine disease is also characterised by tissue damage, including endometrial cytolysis caused by the cholesteroldependent cytolysin, pyolysin. The responses to pathogens are energetically expensive, and depletion of the key cellular nutrients, glucose or glutamine, impairs inflammatory responses by endometrial tissues. For sustainable intensification of the dairy industry over the next 50 years, it is vital to understand why high-milkyield cows are so susceptible to uterine pathology and develop new ways to prevent uterine disease.
\end{abstract}

Keywords: cow, immunity, infertility, metritis, ovary, uterus.

\section{Introduction}

Bacterial infections of the endometrium that cause uterine disease are common in modern dairy cattle after parturition, and lead to decreased productivity and subfertility (Sheldon et al., 2009). The rising incidence of postpartum metritis and endometritis over the last 50 years has generated interest in better understanding the characteristics of the diseases and the impact of the disease on animal health. There has also been a parallel increase in understanding of the mechanisms underlying uterine disease in dairy cattle. Here we provide an overview of postpartum uterine infection and disease in dairy cattle.

\section{Definitions of uterine diseases}

The definitions of the various uterine diseases in the literature varied considerably until 2006, when a series of definitions were formulated, with consensus amongst about 20 international experts and referees prior to publication (Sheldon et al., 2006). The initial definitions are now widely used, as set out in 2006 or with minor modifications (Sheldon et al., 2009; de Boer et al., 2014).

The two main postpartum clinical conditions are metritis and endometritis. Metritis is most common within 10 days of parturition, and is characterized by an enlarged uterus containing a watery red-brown fluid to viscous off-white purulent uterine discharge, which often has a fetid odour. The severity of metritis is categorized by the signs of the animal's health, from mild disease to toxaemia. The incidence of metritis varies between breed, country and herd, but in a study of the records from 97,318 cows in the USA, the lactation incidence of metritis, including retained placenta, was $21 \%$ (Zwald et al., 2004). Clinical endometritis is defined as the presence of a purulent discharge detectable in the vagina 21 days or more post partum, or mucopurulent discharge detectable in the vagina after 26 days post partum. The incidence of clinical endometritis is around 10 to $20 \%$, with variation between breed, country and herd; a typical study reported that $16.9 \%$ of 1,865 cows were affected in Canada (LeBlanc et al., 2002). One of the determinants of the likelihood of uterine disease is the incidence of risk factors. These risk factors can be divided into factors that are associated with damage to the uterus, metabolic stress, or deficits in hygiene. Interestingly, the latter is the least important in the majority of epidemiological models that quantify the risk factors for uterine disease (Dubuc et al., 2010; Potter et al., 2010; Sheldon, 2014). The risk factors most frequently associated with uterine infection are those that likely lead to some trauma to the endometrium, including stillbirth, twins, male and beefsire calves, dystocia, caesarean section operation, and retained placenta (Hussain et al., 1990; Peeler et al., 1994; Dubuc et al., 2010; Potter et al., 2010).

The diagnosis of metritis and clinical endometritis should include an inspection of the contents of the female genital tract by speculum or insertion of a clean-gloved-hand into the vagina (Sheldon, 2004; Sheldon et al., 2006; de Boer et al., 2014). Whilst somewhat invasive, examination of the vagina carries little risk of further microbial contamination of the uterus in postpartum dairy 
cattle (Sheldon et al., 2002a). Manual examination of the vagina also facilitates collection of fluid from the vagina to evaluate the presence and odour of pus, which can be used to score the severity of disease and predict the likely success of treatment (Sheldon et al., 2006). Vaginal examination also allows the operator to detect damage to the wall of the vagina and cervix, indicative of obstetric injuries, vaginitis, and cervicitis. However, as with any clinical examination, the evaluation of uterine disease is subjective and there is inter- and intraoperator variation (Sannmann and Heuwieser, 2015).

The absence of pus in the postpartum genital tract does not mean that the tract is normal. The importance of subclinical endometritis has emerged over the last 15 years, with the realisation that cytological evidence of inflammation of the endometrium is associated with reduced fertility (Kasimanickam et al., 2004; Gilbert et al., 2005). The cause of subclinical endometritis is not yet clear, and may include resolving bacterial infections, immune-pathology without pathogenic bacteria, or even aberrations of postpartum tissue regeneration and repair. Subclinical endometritis is characterized by inflammation of the endometrium that results in a significant reduction in reproductive performance in the absence of signs of clinical endometritis. Subclinical disease is defined by the proportion of polymorphonuclear neutrophils (PMNs) exceeding operator-defined thresholds, usually about 5\% of cells in samples collected by flushing the uterine lumen or by endometrial cytobrush, in the absence of clinical endometritis, about 35 to 40 days post partum (Sheldon et al., 2006; de Boer et al., 2014).

Pyometra is characterized by the accumulation of purulent or mucopurulent material within the uterine lumen and distension of the uterus, in the presence of a closed cervix and an active corpus luteum. Postpartum pyometra is uncommon, with an incidence rate of less than $2 \%$, and is thought to be caused by the growth of pathogenic bacteria within the uterine lumen after the formation of the first corpus luteum (Noakes et al., 1990). Although there is functional closure of the cervix, the lumen is not always completely occluded and pus may occasionally discharge through the cervix into the vaginal lumen. Pyometra is sonographically characterised by mixed echodensity fluid in the uterine lumen with distension of the uterus, and a corpus luteum in an ovary (Sheldon et al., 2006).

\section{The postpartum period}

Uterine disease reflects a disturbance of the normal postpartum period, which usually lasts about 40 days, and is defined as the time between parturition and completion of uterine involution (Sheldon, 2004). After parturition, four concomitant events need to be completed before cows are likely to be able to conceive again: uterine involution, regeneration of the endometrium, return of ovarian cyclic activity, and the control of pathogenic bacteria in the uterus (Sheldon, 2004; Sheldon et al., 2006). Failure to resist the growth of pathogenic microbes in the endometrium commonly results in uterine disease.

\section{Uterine involution}

Involution is the term used to describe the physical reduction in size of the uterus and cervix after parturition. Involution is thought to be driven by uterine muscular contractions, turnover of the extracellular matrix, necrosis and sloughing of the uterine caruncles, and regeneration of the endometrium (Gier and Marion, 1968). It is often difficult to insert a hand through the cervix $24 \mathrm{~h}$ after parturition, and it only admits two fingers by $96 \mathrm{~h}$ postpartum. By about 2 weeks post partum, the entire genital tract is palpable per rectum in normal animals; although, the previously gravid horn can still be identified because it is wider and longer than the previously non-gravid horn, and this difference is evident up to 4 weeks postpartum (Okano and Tomizuka, 1987; Tian and Noakes, 1991b; Risco et al., 1994). In parallel with the changes in dimensions, the weight of the uterus decreases from about $9 \mathrm{~kg}$ at parturition to $1 \mathrm{~kg}$ by 30 days postpartum (Gier and Marion, 1968).

Uterine involution can be monitored by repeated estimation of the size of the uterus, using transrectal palpation or transrectal ultrasonography (Okano and Tomizuka, 1987; Sheldon et al., 2000, 2003). It should be noted that dimensions estimated by transrectal palpation are often about 1 to $2 \mathrm{~cm}$ greater than ultrasound measurements; presumably because operators include the thickness of the rectal wall when using transrectal palpation. The changes in uterine horn diameter are almost imperceptible by 4 weeks postpartum, and are probably complete by 6 weeks. In the literature, the time to completion of uterine involution is often reported, but this endpoint is difficult to estimate in clinical practice. On the other hand, factors that delay uterine involution are important because completion of involution is associated with fertility (Fonseca et al., 1983). The factors that delay involution include dystocia, hypocalcaemia, retained placenta, metritis, and endometritis.

\section{Regeneration of the endometrium}

The epithelium of the endometrium is often damaged during parturition, the caruncular tissue sloughs as part of the physiological process of the puerperium, and there is considerable tissue remodelling during the postpartum period (Gier and Marion, 1968; Wagner and Hansel, 1969; Tian and Noakes, 1991a). It is thought that the endometrium takes 3 to 4 weeks to fully recover the normal tissue architecture, and it is assumed that a normal endometrium is important for fertility.

\section{Return of ovarian cyclic activity}

Within a few days of parturition, circulating steroid hormone concentrations decrease to basal values, and there is an increase in plasma FSH concentration, with subsequent recurrent increases in FSH concentrations every 7 to 10 days (Crowe et al., 1998; Duffy et al., 2000). The first postpartum dominant follicle, with a diameter $>8 \mathrm{~mm}$, is usually 
selected about 10 days after parturition. This dominant follicle may ovulate to form the first postpartum corpus luteum, the dominant follicle may undergo atresia with subsequent emergence of a second dominant follicle, or it may abnormally persist as an ovarian cyst (Savio et al., 1990; Stagg et al., 1995; Beam and Butler, 1997). The fate of the first postpartum dominant follicle depends on $\mathrm{LH}$ pulse frequency, and failure to ovulate is usually a consequence of inadequate LH pulse frequency and reduced ovarian follicle estradiol (Beam and Butler, 1999; Duffy et al., 2000; Cheong et al., 2016). In dairy cattle, metabolic stress - most often negative energy balance - is the main cause of reduced $\mathrm{LH}$ pulse frequency, although a range of other factors can impact ovarian cyclic activity (Cheong et al., 2016).

\section{Microbes that cause uterine disease}

Postpartum uterine disease is associated with the isolation of pathogenic bacteria, particularly Escherichia coli, Trueperella pyogenes, Fusobacterium necrophorum, Prevotella and Bacteroides (Elliott et al., 1968; Griffin et al., 1974; Huszenicza et al., 1991; Noakes et al., 1991). Indeed, $T$. pyogenes, $F$. necrophorum and Prevotella act synergistically to increase the likelihood and the severity of endometritis (Ruder et al., 1981; Olson et al., 1984). More recent studies using aerobic and anaerobic culture confirm the importance of E. coli, T. pyogenes and anaerobic bacteria (Dohmen et al., 2000; Sheldon et al., 2002b; Williams et al., 2005; Westermann et al., 2010). Novel endometrial pathogenic $E$. coli have been isolated from animals with uterine disease (Sheldon et al., 2010); and, $T$. pyogenes is associated with the severity of endometrial pathology and clinical disease (Bonnett et al., 1991; Westermann et al., 2010). The link between $T$. pyogenes and disease may be explained by the cholesterol-dependent cytolysin pyolysin (PLO) secreted by $T$. pyogenes, which causes cytolysis particularly of endometrial stromal cells (Amos et al., 2014; Preta et al., 2015).

The role of $E$. coli and $T$. pyogenes is highlighted by infusing $E$. coli and $T$. pyogenes into the uterus of naïve cows to create animal models of endometritis (Ayliffe and Noakes, 1982; Amos et al., 2014). In addition, vaccines containing components of E. coli, $F$. necrophorum and/or $T$. pyogenes protect animals against postpartum uterine disease (Nolte et al., 2001; Machado et al., 2014). However, metagenomics techniques have found associations between uterine disease and bacteria that are not readily cultured by standard techniques (Machado et al., 2012; Santos and Bicalho, 2012; Peng et al., 2013; Knudsen et al., 2015; Wagener et al., 2015). Whilst some of the studies find E. coli, T. pyogenes and the expected anaerobic bacteria, others report finding Bacteroidetes and Firmicutes. There remains a gap in understanding how "uncultureable" bacteria contribute to the pathogenesis of uterine disease. A consistent finding among most microbiology studies is that anaerobic bacteria are more abundant in the diseased endometrium than in healthy uteri. Perhaps this is not surprising as the endometrium is a microaerophilic environment, with tissue damage likely reducing the oxygen tension further. Taken together the evidence is that E. coli, T. pyogenes and anaerobic bacteria are probably the main pathogens causing the clinical signs of postpartum uterine disease (Fig. 1).

One note of caution about our understanding of microbes in the endometrium is that recent evidence counters the traditional view that the uterus is sterile outside the postpartum period. There is evidence from studies using fluorescent probes for bacteria and from $16 \mathrm{~S}$ ribosomal RNA gene sequencing, that there is a sparse microbiome in the uterus, even during pregnancy (Karstrup et al., 2017; Moore et al., 2017). The bacteria include Trueperella, Fusobacteria and Prevotella species, but the abundance of these bacteria is a small fraction of those present in animals with postpartum uterine disease. Whilst postpartum uterine bacteria may also derive from the vagina, skin and the environment, it is possible that the pathogenic bacteria present in the uterus before parturition grow and cause pathology after parturition.

\section{Host defence against infections of the uterus}

The host has a range of defences against microbial contamination of the uterus and infection of the endometrium. Whilst the animals' environment is heavily contaminated with bacteria, the vulva, vagina and cervix provide anatomical barriers to ascending infections, except during parturition (Fig. 1). Whether the resident flora of the vagina or the $\mathrm{pH}$ of the vagina might also compete with pathogens to limit disease is a contentious matter. However, there is a range of antimicrobial peptides, glycoproteins and mucins in the vagina, cervix and uterus, that counter bacterial contamination and restrain bacterial growth (Davies et al., 2008; Chapwanya et al., 2013; Kasimanickam et al., 2014).

Of course, microbial invasion of the female genital tract is not unnoticed. Adaptive immune responses are evident, with increase abundance of antibodies (Dhaliwal et al., 2001); which, concur with the ability to vaccinate against uterine pathogens (Nolte et al., 2001; Machado et al., 2014). A recent advance in knowledge has been about the role of innate immunity in the female genital tract (Fig. 1). Innate immunity depends on the binding of pathogen-associated molecular patterns from microbes to pattern recognition receptors in host cells. There is a range of pattern recognition receptors found in the plasma membrane or cytoplasm of mammalian hematopoietic cells. The two most widely investigated pattern recognition receptor families are the Toll-like receptors and components of the inflammasome (Moresco et al., 2011; Lamkanfi and Dixit, 2014). The Toll-like receptors bind components of bacteria, such as lipopolysaccharide, lipopeptides and nucleotides, which leads to production of inflammatory mediators; typically interleukin (IL)-6 and IL-8. Similarly, pathogen-associated molecules that reach intracellular compartments activate the inflammasome. However, the inflammasome can also be activated by a 
range of generalized cell perturbations, including the ion fluxes that are associated with pore-forming toxins secreted by bacteria. Activation of the inflammasome typically leads to cleavage of pro-IL- $1 \beta$ and secretion of the mature form of IL-1 $\beta$ (Lamkanfi and Dixit, 2014). The Toll-like receptor system is present and active in the cells of the endometrium, both epithelium and stroma, as well as in bovine hematopoietic cells (Herath et al., 2006; Cronin et al., 2012, 2016; Turner et al., 2014). However, endometrial cells secrete little IL-1 $\beta$ protein, and so inflammasome activity may be more important in hematopoietic cells.

The innate immune system provides a nonspecific and rapid response to pathogens and damage. However, excessive inflammation leads to immunopathology or septic shock, and so innate immunity is carefully calibrated. A series of checks and balances are in place to scale inflammation to meet the level of microbial threat, and to limit inflammation when infections are cleared (Blander and Sander, 2012). One example in the bovine endometrium, is the role of STAT3 to regulate the secretion of IL- 6 and IL- 8 in stromal cells (Cronin et al., 2016). Another example is the apical secretion of IL- 6 and IL- 8 from bovine endometrial epithelial cells, toward the invading pathogens in the uterine lumen and away from the underlying stromal cells (Healy et al., 2015).

Beyond recognition of microbes, one of the features of infection is tissue damage, which in the endometrium is often caused by secretion of pyolysin by T. pyogenes (Amos et al., 2014; Preta et al., 2015). Damaged cells release damage-associated molecular patterns, such as nuclear and cytoplasmic molecules that are not normally encountered in the extra-cellular compartment (Kono and Rock, 2008). Some pattern recognition receptors, primarily in hematopoietic cells, sense damage-associated molecular patterns, leading to inflammatory responses. Damaged endometrial tissue cells, primed with LPS, produce the damage-associated molecular patterns, IL- $1 \alpha$, which is normally retained in the cytoplasm of healthy cells (Healy et al., 2014). Furthermore, endometrial stromal cells express the receptor for IL-1 and generate inflammatory responses to IL-1 $\alpha$, including secretion of more IL-6 (Healy et al., 2014).

Innate immunity is an evolutionary ancient system and so it is not surprising that it is integrated with other cellular homeostatic and metabolic pathways (Kotas and Medzhitov, 2015). Dairy cattle are under metabolic stress after parturition, with reduced concentrations of nutrients and changes in metabolic hormones, including reduced abundance of glucose, glutamine and insulin-like growth factor 1 (Chagas et al., 2007; Kerestes et al., 2009). Negative energy balance may impair the inflammatory response and clearance of bacteria from the endometrium, leading to chronic endometritis (Esposito et al., 2014). Certainly, the response to pathogen molecules is energetically expensive in vivo and in vitro (Turner et al., 2016; Kvidera et al., 2017). A striking example is that animals use $>1 \mathrm{~kg}$ of glucose in the first $12 \mathrm{~h}$ after challenge with LPS (Kvidera et al., 2017). Furthermore, the depletion of the key cellular nutrients, glucose or glutamine, reduces inflammatory responses by endometrial tissues in vitro (Turner et al., 2016; Noleto et al., 2017). If metabolic stress compromises the ability of animals to respond sufficiently to pathogens, this may result in persistence of infections and chronic inflammation.

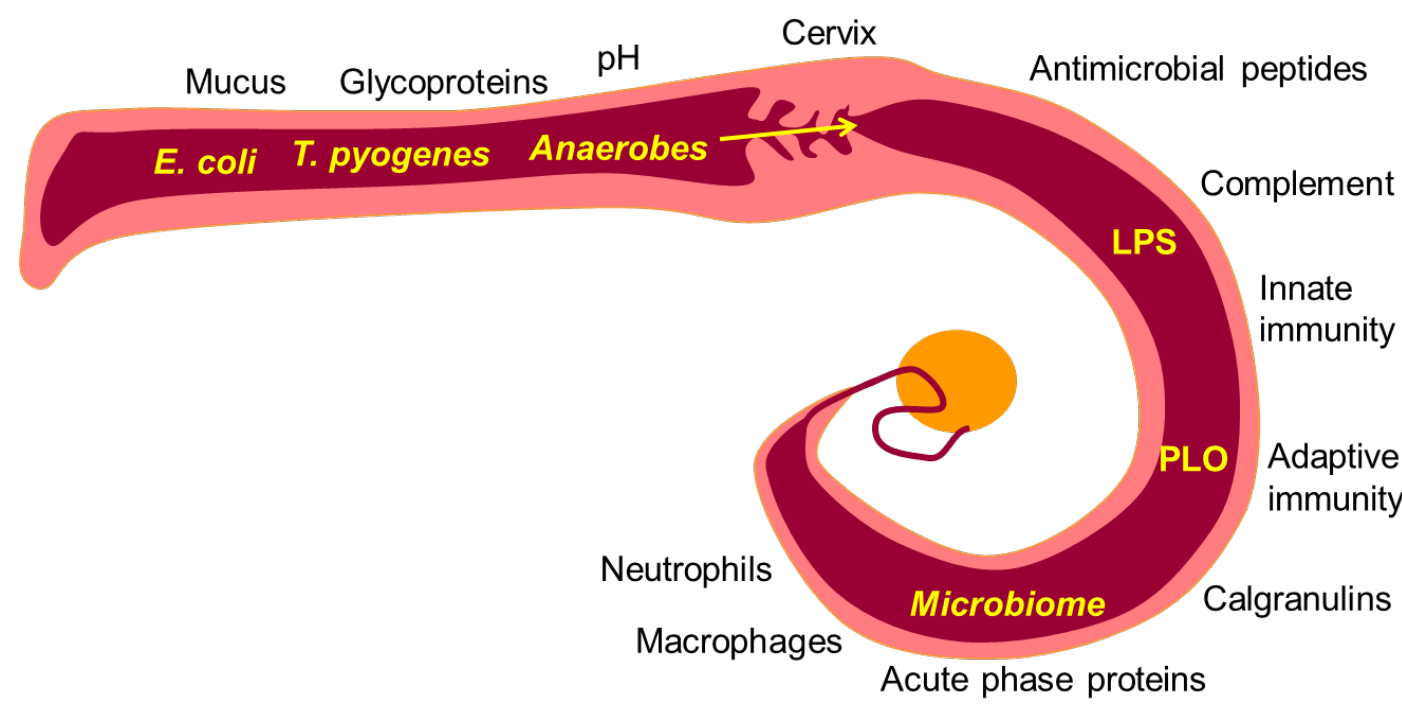

Figure 1. Schematic outline of factors contributing to postpartum uterine health. After parturition the anatomical barriers of the vulva, vagina and cervix are breached, introducing bacteria into the uterus, including pathogens, along with bacteria that constitute the uterine microbiome. However, tissue factors such as mucus, glycoproteins, the $\mathrm{pH}$ of the genital tract, and antimicrobial peptides help counter bacterial invasion. If bacteria or their pathogenassociated molecules, such as lipopolysaccharide (LPS), are sensed by the innate or adaptive immune systems then an inflammatory response ensues, including increased expression of complement, calgranulins and acute phase proteins, and chemotaxis of neutrophils and macrophages to the site of infection. As well as inflammation, uterine disease is characterised by tissue damage, including cytolysis caused by the cholesterol-dependent cytolysin, pyolysin (PLO). 


\section{Impact of uterine disease on animal health and fertility}

Clinical uterine disease has a marked impact on reproductive health in cattle, causing subfertility and infertility. In a meta-analysis of records from more than 10,000 animals, there was evidence that postpartum metritis caused subfertility by increasing the time to first insemination by 7.2 days, reducing conception rate to first insemination by $20 \%$, and increasing the calving to conception interval by 18.6 days (Fourichon et al., 2000). Similarly, clinical endometritis increased the interval to first insemination by 11 days, and delayed conception by 32 days, compared with animals that did not have endometritis (Borsberry and Dobson, 1989). Although less common than subfertility, uterine disease also cause infertility. Cows with clinical endometritis between 20 and 33 days post partum were 1.7 times more likely to be culled for reproductive failure than cows without endometritis (LeBlanc et al., 2002).

Pathology in the endometrium is likely to be detrimental to fertilization and conception. In addition, extension of infection or inflammation to the oviduct likely disrupts the delicate balance of the immune systems that are required for fertilization (Marey et al., 2016). However, an important observation for mechanisms that perturb fertility, is that postpartum uterine infection also impacts fertility after resolution of the clinical disease (Borsberry and Dobson, 1989). Several mechanisms may underlie the wider effects of uterine infection on fertility, beyond the tubular genital tract. First, there is evidence that bacterial infections disrupt the endocrine signalling in the hypothalamicpituitary-gonadal axis, and the secretion of gonadotrophins (Karsch et al., 2002). Secondly, uterine infections disrupt ovarian follicle growth and function, with smaller and less steroidogenic ovarian follicles (Sheldon et al., 2002b). Finally, uterine infections may reduce oocyte quality, with increased rates of meiotic arrest and germinal vesicle breakdown failure (Bromfield and Sheldon, 2011). Oocyte development lasts about 120 days, between the primordial follicle stage to ovulation of a cumulus-oocyte complex. Thus, in cows inseminated 60 to 120 days post partum, the oocytes that are ovulated may have been exposed to pathogen molecules and inflammatory mediators throughout the postpartum period, if the animal had uterine disease. Therefore, limiting uterine disease is not only important for the affected animals, but also for their offspring. Further discussion of the mechanisms linking uterine disease and reproductive biology are published elsewhere (Sheldon et al., 2014; Bromfield et al., 2015).

\section{Outstanding questions}

Whilst there is a clear understanding of the clinical aspects and implication of postpartum uterine disease, and some of the mechanisms of pathology, there are important outstanding questions. The most obvious question is why are modern high-milk-yield cows so susceptible to metritis and endometritis? Allied to this, is what can be done to prevent uterine disease? Answering these questions is vital for sustainable intensification of the dairy industry over the next 50 years.

\section{Acknowledgments}

Work in the Sheldon laboratory was funded by the Biotechnology and Biological Sciences Research Council (BB/I017240/1; BB/K006592/1).

\section{References}

Amos MR, Healey GD, Goldstone RJ, Mahan S, Duvel A, Schuberth HJ, Sandra O, Zieger P, DieuzyLabaye I, Smith DGE, Sheldon IM. 2014. Differential endometrial cell sensitivity to a cholesterol-dependent cytolysin links Trueperella pyogenes to uterine disease in cattle. Biol Reprod, 90:54,1-13.

Ayliffe TR, Noakes DE. 1982. Effects of exogenous oestrogen and experimentally induced endometritis on absorption of sodium benzylpenicillin from the cow's uterus. Vet Rec, 110:96-98.

Beam SW, Butler WR. 1997. Energy balance and ovarian follicle development prior to the first ovulation postpartum in dairy cows receiving three levels of dietary fat. Biol Reprod, 56:133-142.

Beam SW, Butler WR. 1999. Effects of energy balance on follicular development and first ovulation in postpartum dairy cows. J Reprod Fertil Suppl, 54:411424.

Blander JM, Sander LE. 2012. Beyond pattern recognition: five immune checkpoints for scaling the microbial threat. Nat Rev Immunol, 12:215-225.

Bonnett BN, Martin SW, Gannon VP, Miller RB, Etherington WG. 1991. Endometrial biopsy in Holstein-Friesian dairy cows. III. Bacteriological analysis and correlations with histological findings. Can $J$ Vet Res, 55:168-173.

Borsberry S, Dobson H. 1989. Periparturient diseases and their effect on reproductive performance in five dairy herds. Vet Rec, 124:217-219.

Bromfield JJ, Sheldon IM. 2011. Lipopolysaccharide initiates inflammation in bovine granulosa cells via the TLR4 pathway and perturbs oocyte meiotic progression in vitro. Endocrinology, 152:5029-5040.

Bromfield JJ, Santos JE, Block J, Williams RS, Sheldon IM. 2015. Physiology and Endocrinology Symposium: Uterine infection: linking infection and innate immunity with infertility in the high-producing dairy cow. J Anim Sci, 93:2021-2033.

Chagas LM, Bass JJ, Blache D, Burke CR, Kay JK, Lindsay DR, Lucy MC, Martin GB, Meier S, Rhodes FM, Roche JR, Thatcher WW, Webb R. 2007. Invited review: New perspectives on the roles of nutrition and metabolic priorities in the subfertility of high-producing dairy cows. J Dairy Sci, 90:4022-4032.

Chapwanya A, Meade KG, Doherty ML, Callanan JJ, O'Farrelly C. 2013. Endometrial epithelial cells are potent producers of tracheal antimicrobial peptide and serum amyloid A3 gene expression in response to $E$. 
coli stimulation. Vet Immunol Immunopathol, 151:157162.

Cheong SH, Sa Filho OG, Absalon-Medina VA, Pelton SH, Butler WR, Gilbert RO. 2016. Metabolic and endocrine differences between dairy cows that do or do not ovulate first postpartum dominant follicles. Biol Reprod, 94:18, 1-11.

Cronin JG, Turner ML, Goetze L, Bryant CE, Sheldon IM. 2012. Toll-Like receptor 4 and MyD88dependent signaling mechanisms of the innate immune system are essential for the response to lipopolysaccharide by epithelial and stromal cells of the bovine endometrium. Biol Reprod, 86:51, 1-9.

Cronin JG, Kanamarlapudi V, Thornton CA, Sheldon IM. 2016. Signal transducer and activator of transcription-3 licenses Toll-like receptor 4-dependent interleukin (IL)-6 and IL-8 production via IL-6 receptor-positive feedback in endometrial cells. Mucosal Immunol, 9:1125-1136.

Crowe MA, Padmanabhan V, Mihm M, Beitins IZ, Roche JF. 1998. Resumption of follicular waves in beef cows is not associated with periparturient changes in follicle-stimulating hormone heterogeneity despite major changes in steroid and luteinizing hormone concentrations. Biol Reprod, 58:1445-1450.

Davies D, Meade KG, Herath S, Eckersall PD, Gonzalez D, White JO, Conlan RS, O'Farrelly C, Sheldon IM. 2008. Toll-like receptor and antimicrobial peptide expression in the bovine endometrium. Reprod Biol Endocrinol, 6:53.

de Boer MW, LeBlanc SJ, Dubuc J, Meier S, Heuwieser W, Arlt S, Gilbert RO, McDougall S. 2014. Invited review: systematic review of diagnostic tests for reproductive-tract infection and inflammation in dairy cows. J Dairy Sci, 97:3983-399.

Dhaliwal GS, Murray RD, Woldehiwet Z. 2001. Some aspects of immunology of the bovine uterus related to treatments for endometritis. Anim Reprod Sci, 67:135-152.

Dohmen MJ, Joop K, Sturk A, Bols PE, Lohuis JA. 2000. Relationship between intra-uterine bacterial contamination, endotoxin levels and the development of endometritis in postpartum cows with dystocia or retained placenta. Theriogenology, 54:1019-1032.

Dubuc J, Duffield TF, Leslie KE, Walton JS, LeBlanc SJ. 2010. Risk factors for postpartum uterine diseases in dairy cows. J Dairy Sci, 93:5764-5771.

Duffy P, Crowe MA, Boland MP, Roche JF. 2000. Effect of exogenous LH pulses on the fate of the first dominant follicle in postpartum beef cows nursing calves. J Reprod Fertil, 118:9-17.

Elliott L, McMahon KJ, Gier HT, Marion GB. 1968 Uterus of the cow after parturition: bacterial content. Am J Vet Res, 29:77-81.

Esposito G, Irons PC, Webb EC, Chapwanya A. 2014. Interactions between negative energy balance, metabolic diseases, uterine health and immune response in transition dairy cows. Anim Reprod Sci, 144:60-71.

Fonseca FA, Britt JH, McDaniel BT, Wilk JC, Rakes AH. 1983. Reproductive traits of Holsteins and Jerseys. Effects of age, milk yield, and clinical abnormalities on involution of cervix and uterus, ovulation, estrous cycles, detection of estrus, conception rate and days open. J Dairy Sci, 66:1128-1147.

Fourichon C, Seegers H, Malher X. 2000. Effect of disease on reproduction in the dairy cow: a metaanalysis. Theriogenology, 53:1729-1759.

Gier HT, Marion GB. 1968. Uterus of the cow after parturition: involutional changes. Am J Vet Res, 29:8396.

Gilbert RO, Shin ST, Guard CL, Erb HN, Frajblat M. 2005. Prevalence of endometritis and its effects on reproductive performance of dairy cows. Theriogenology, 64:1879-1888.

Griffin JFT, Hartigan PJ, Nunn WR. 1974. Nonspecific uterine infection and bovine fertility. I. Infection patterns and endometritis during the first seven weeks post-partum. Theriogenology, 1:91-106.

Healy LL, Cronin JG, Sheldon IM. 2014. Endometrial cells sense and react to tissue damage during infection of the bovine endometrium via interleukin 1. Sci Rep, 4:7060, 1-9. doi:10.1038/srep07060.

Healy LL, Cronin JG, Sheldon IM. 2015. Polarized epithelial cells secrete interleukin 6 apically in the bovine endometrium. Biol Reprod, 92:151, 1-12.

Herath S, Fischer DP, Werling D, Williams EJ, Lilly ST, Dobson H, Bryant CE, Sheldon IM. 2006. Expression and function of Toll-like receptor 4 in the endometrial cells of the uterus. Endocrinology, 147:562570.

Hussain AM, Daniel RCW, O'Boyle D. 1990. Postpartum uterine flora following normal and abnormal puerperium in cows. Theriogenology, 34:291-302.

Huszenicza G, Fodor M, Gacs M, Kulcsar M, Dohmen MJW, Vamos M, Porkolab L, Legl T, Bartyik J, Lohuis JACM, Janosi S, Szita G. 1991. Uterine bacteriology, resumption of cyclic ovarian activity and fertility in postpartum cows kept in largescale dairy herds. Reprod Domest Anim, 34:237-245.

Karsch FJ, Battaglia DF, Breen KM, Debus N, Harris TG. 2002. Mechanisms for ovarian cycle disruption by immune/inflammatory stress. Stress, 5:101-112.

Karstrup CC, Klitgaard K, Jensen TK, Agerholm JS, Pedersen HG. 2017. Presence of bacteria in the endometrium and placentomes of pregnant cows. Theriogenolgy, 99:43-47.

Kasimanickam R, Duffield TF, Foster RA, Gartley CJ, Leslie KE, Walton JS, Johnson WH. 2004. Endometrial cytology and ultrasonography for the detection of subclinical endometritis in postpartum dairy cows. Theriogenology, 62:9-23.

Kasimanickam R, Kasimanickam V, Kastelic JP. 2014. Mucin 1 and cytokines mRNA in endometrium of dairy cows with postpartum uterine disease or repeat breeding. Theriogenology, 81:952-958 e2.

Kerestes M, Faigl V, Kulcsar M, Balogh O, Foldi J, Febel H, Chilliard Y, Huszenicza G. 2009. Periparturient insulin secretion and whole-body insulin responsiveness in dairy cows showing various forms of ketone pattern with or without puerperal metritis. Domest Anim Endocrinol, 37:250-261.

Knudsen LR, Karstrup CC, Pedersen HG, Agerholm JS, Jensen TK, Klitgaard K. 2015. Revisiting bovine 
pyometra--new insights into the disease using a cultureindependent deep sequencing approach. Vet Microbiol, 175:319-324.

Kono H, Rock KL. 2008. How dying cells alert the immune system to danger. Nat Rev Immunol, 8:279-89.

Kotas ME, Medzhitov R. 2015. Homeostasis, inflammation, and disease susceptibility. Cell, 160:816827.

Kvidera SK, Horst EA, Abuajamieh M, Mayorga EJ, Fernandez MV, Baumgard LH. 2017. Glucose requirements of an activated immune system in lactating Holstein cows. J Dairy Sci, 100:2360-2374.

Lamkanfi M, Dixit VM. 2014. Mechanisms and functions of inflammasomes. Cell, 157:1013-1022.

LeBlanc SJ, Duffield TF, Leslie KE, Bateman KG, Keefe GP, Walton JS, Johnson WH. 2002. Defining and diagnosing postpartum clinical endometritis and its impact on reproductive performance in dairy cows. $J$ Dairy Sci, 85:2223-2236.

Machado VS, Bicalho ML, Meira Junior EB, Rossi R, Ribeiro BL, Lima S, Santos T, Kussler A, Foditsch C, Ganda EK, Oikonomou G, Cheong SH, Gilbert RO, Bicalho RC. 2014. Subcutaneous immunization with inactivated bacterial components and purified protein of Escherichia coli, Fusobacterium necrophorum and Trueperella pyogenes prevents puerperal metritis in Holstein dairy cows. PLOS One, 9:e91734.

Machado VS, Oikonomou G, Bicalho ML, Knauer WA, Gilbert R, Bicalho RC. 2012. Investigation of postpartum dairy cows' uterine microbial diversity using metagenomic pyrosequencing of the $16 \mathrm{~S}$ rRNA gene. Vet Microbiol, 159:460-469.

Marey MA, Yousef MS, Kowsar R, Hambruch N, Shimizu T, Pfarrer C, Miyamoto A. 2016. Local immune system in oviduct physiology and pathophysiology: attack or tolerance? Domest Anim Endocrinol, 56(suppl):S204-211.

Moore SG, Ericsson AC, Poock SE, Melendez P, Lucy MC. 2017. Hot topic: 16S rRNA gene sequencing reveals the microbiome of the virgin and pregnant bovine uterus. J Dairy Sci, 100:4953-4960.

Moresco EM, LaVine D, Beutler B. 2011. Toll-like receptors. Curr Biol, 21:R488-93.

Noakes DE, Wallace LM, Smith GR. 1990. Pyometra in a Friesian heifer: bacteriological and endometrial changes. Vet Rec, 126:509.

Noakes DE, Wallace L, Smith GR. 1991. Bacterial flora of the uterus of cows after calving on two hygienically contrasting farms. Vet Rec, 128:440-442.

Noleto PG, Saut JP, Sheldon IM. 2017. Short communication: Glutamine modulates inflammatory responses to lipopolysaccharide in ex vivo bovine endometrium. J Dairy Sci, 100:2207-2212.

Nolte O, Morscher J, Weiss HE, Sonntag H. 2001. Autovaccination of dairy cows to treat post partum metritis caused by Actinomyces pyogenes. Vaccine, 19:3146-3153.

Okano A, Tomizuka T. 1987. Ultrasonic observation of postpartum uterine involution in the cow. Theriogenology, 27:369-376.

Olson JD, Ball L, Mortimer RG, Farin PW, Adney
WS, Huffman EM. 1984. Aspects of bacteriology and endocrinology of cows with pyometra and retained fetal membranes. Am J Vet Res, 45:2251-2255.

Peeler EJ, Otte MJ, Esslemont RJ. 1994. Interrelationships of periparturient diseases in dairy cows. Vet Rec, 134:129-132.

Peng Y, Wang Y, Hang S, Zhu W. 2013. Microbial diversity in uterus of healthy and metritic postpartum Holstein dairy cows. Folia Microbiol (Praha), 58:593600.

Potter T, Guitian J, Fishwick J, Gordon PJ, Sheldon IM. 2010. Risk factors for clinical endometritis in postpartum dairy cattle. Theriogenology, 74:127-134.

Preta G, Lotti V, Cronin JG, Sheldon IM. 2015. Protective role of the dynamin inhibitor Dynasore against the cholesterol-dependent cytolysin of Trueperella pyogenes. FASEB J, 29:1516-1528.

Risco CA, Drost M, Thatcher WW, Savio J, Thatcher MJ. 1994. Effects of calving-related disorders on prostaglandin, calcium, ovarian activity and uterine involution in postpartum dairy cows. Theriogenology, 42:183-203.

Ruder CA, Sasser RG, Williams RJ, Ely JK, Bull RC, Butler JE. 1981. Uterine infections in the postpartum cow: II Possible synergistic effect of Fusobacterium necrophorum and Corynebacterium pyogenes. Theriogenology, 15:573-580.

Sannmann I, Heuwieser W. 2015. Technical note: Intraobserver, interobserver, and test-retest reliabilities of an assessment of vaginal discharge from cows with and without acute puerperal metritis. $J$ Dairy $S c i$, 98:5460-5466.

Santos TM, Bicalho RC. 2012. Diversity and succession of bacterial communities in the uterine fluid of postpartum metritic, endometritic and healthy dairy cows. PLOS One, 7:e53048.

Savio JD, Boland MP, Hynes N, Roche JF. 1990. Resumption of follicular activity in the early postpartum period of dairy cows. J Reprod Fertil, 88:569-579.

Sheldon IM, Noakes DE, Dobson H. 2000. The influence of ovarian activity and uterine involution determined by ultrasonography on subsequent reproductive performance. Theriogenology, 54:409-419. Sheldon IM, Noakes DE, Rycroft AN, Dobson $H$. 2002a. Effect of postpartum manual examination of the vagina on uterine bacterial contamination in cows. Vet Rec, 151:531-534.

Sheldon IM, Noakes DE, Rycroft AN, Pfeiffer DU, Dobson H. 2002b. Influence of uterine bacterial contamination after parturition on ovarian dominant follicle selection and follicle growth and function in cattle. Reproduction, 123:837-845.

Sheldon IM, Noakes DE, Rycroft AN, Dobson H. 2003. The effect of intrauterine administration of estradiol on postpartum uterine involution in cattle. Theriogenology, 59:1357-1371.

Sheldon IM. 2004. The postpartum uterus. Vet Clin North Am Food Anim Pract, 20:569-591.

Sheldon IM, Lewis GS, LeBlanc S, Gilbert RO. 2006. Defining postpartum uterine disease in cattle. Theriogenology, 65:1516-1530.

Sheldon IM, Cronin J, Goetze L, Donofrio G, 
Schuberth HJ. 2009. Defining postpartum uterine disease and the mechanisms of infection and immunity in the female reproductive tract in cattle. Biol Reprod, 81:1025-1032.

Sheldon IM, Rycroft AN, Dogan B, Craven M, Bromfield JJ, Chandler A, Roberts MH, Price SB, Gilbert RO, Simpson KW. 2010. Specific strains of Escherichia coli are pathogenic for the endometrium of cattle and cause pelvic inflammatory disease in cattle and mice. PLOS One, 5:e9192.

Sheldon IM. 2014. Genes and environmental factors that influence disease resistance to microbes in the female reproductive tract of dairy cattle. Reprod Fertil Dev, 27:72-81.

Sheldon IM, Cronin JG, Healey GD, Gabler C, Heuwieser W, Streyl D, Bromfield JJ, Miyamoto A, Fergani C, Dobson H. 2014. Innate immunity and inflammation of the bovine female reproductive tract in health and disease. Reproduction, 148:R41-R51.

Stagg K, Diskin MG, Sreenan JM, Roche JF. 1995. Follicular development in long-term anoestrous suckler beef cows fed two levels of energy postpartum. Anim Reprod Sci, 38:49-61.

Tian W, Noakes DE. 1991a. A radiographic method for measuring the effect of exogenous hormone therapy on uterine involution in ewes. Vet Rec, 129:463-466.

Tian W, Noakes DE. 1991b. Plasma 3 methyl-histidine concentrations and uterine involution in the post partum cow. Vet Rec, 128:109-110.

Turner ML, Cronin JC, Healey GD, Sheldon IM. 2014. Epithelial and stromal cells of bovine endometrium have roles in innate immunity and initiate inflammatory responses to bacterial lipopeptides in vitro via Toll-like receptors TLR2, TLR1 and TLR6. Endocrinology, 155:1453-1465.

Turner ML, Cronin JG, Noleto PG, Sheldon IM. 2016. Glucose availability and AMP-activated protein kinase link energy metabolism and innate immunity in the bovine endometrium. PLOS One, 11:e0151416.

Wagener K, Prunner I, Pothmann H, Drillich M, Ehling-Schulz M. 2015. Diversity and health status specific fluctuations of intrauterine microbial communities in postpartum dairy cows. Vet Microbiol, 175:286-293.

Wagner WC, Hansel W. 1969. Reproductive physiology of the post partum cow. 1. Clinical histological findings. J Reprod Fertil, 18:493-500.

Westermann S, Drillich M, Kaufmann TB, Madoz LV, Heuwieser W. 2010. A clinical approach to determine false positive findings of clinical endometritis by vaginoscopy by the use of uterine bacteriology and cytology in dairy cows. Theriogenology, 74:1248-1255. Williams EJ, Fischer DP, England GCW, Dobson H, Pfeiffer DU, Sheldon IM. 2005. Clinical evaluation of postpartum vaginal mucus reflects uterine bacterial infection and the inflammatory response to endometritis in cattle. Theriogenology, 63:102-117.

Zwald NR, Weigel KA, Chang YM, Welper RD, Clay JS. 2004. Genetic selection for health traits using producer-recorded data. I. Incidence rates, heritability estimates, and sire breeding values. $J$ Dairy Sci, $87: 4287-4294$ 